\title{
From E-Quality and Brand Perceptions to Repurchase: A Model to Explain Purchase Behaviour in a Web-Store
}

\section{Fabiola Vásquez $^{1}$ y Jorge Vera-Martínez ${ }^{2}$}

\author{
${ }^{1}$ Tecnologico de Monterrey, Business School, Mexico City, Mexico, fabiola.vasquez@tec.mx \\ ${ }^{2}$ Tecnologico de Monterrey, EGADE Business School, Mexico City, Mexico, jorge.vera@tec.mx
}

Received 3 October 2018; received in revised form 9 July 2019; accepted 1 October 2019

\begin{abstract}
This study proposes an explanatory model of repurchase behaviour in web-stores introducing certain relationships not taken into consideration before. However, some established relationships are taken from the literature, such as that between web-store quality, satisfaction and trust. A detailed exploration of measurements was performed to design a structured questionnaire. With a sample of $n=500$ web-store buyers, a structural statistic model was developed to confirm the hypotheses that support the model. A high degree of determination for behavioural intentions was found, and a moderate one for repurchase. Contrasting with previous research this model proposes product brand perception and store brand perception as predictors of trust and intentions in a web-store. As the final dependent variable, a multi-item measurement for repurchase is proposed, tested and discussed; this has not been attempted before for this kind of model.
\end{abstract}

Keywords: Web-store quality, Store brand perception, Customer satisfaction, Trust, Store loyalty, Repurchase 


\section{Introduction}

The Internet has increasingly attracted the attention of established retailers and new e-commerce website endeavors. E-commerce operations now span to all industries. The question is no longer whether to go e-commerce, but how to create a more competitive strategy in this business channel. Firms are making significant investments in this growing online market. A multi-channel environment like this offers consumers convenient additional channels to make purchases. Given the significant expansion in the uses of e-commerce, and the ever-greater dependence on it of both consumers and businesses as a major means for transactions and procurement, it is important to identify factors that could enable e-businesses to achieve customer satisfaction and firm competitiveness. This requires the understanding of customer needs in the context of virtual services. Despite the practicality of e-commerce and the growth of this channel worldwide, we believe that several areas of research relevant to e-commerce operations remain unexplored.

The present study attempts to enrich the understanding of the factors behind behavioural intentions and repurchase in a web-store. These include e-quality dimensions, product and store brand perceptions, satisfaction, and customer trust. Thus, a conceptual framework for an explanatory model is proposed to account for the hypothesized relationships between these constructs, thereby lending support to the model. In addition to supporting the proposed model, this study seeks to address three gaps in the research literature on web-store consumer behaviour: 1) the effect of store brand perception on trust and behavioural intentions; 2) the effect of product brand perception on trust and behavioural intentions; and 3) the effect of trust and behavioural intentions on repurchase patterns.

Hence, an ampler model than is to be found in previous research literature is offered to explain customer loyalty in a web-store. Although many of the constructs outlined here have been partially related to each other in previous studies [66], [79], [92], [112], [128], new relationships are also proposed here for analysis and discussion (such as the effects of store brand and product brand on a web-store and the relationships between trust and behavioural intentions with repurchase patterns in the same context). In addition, according to the authors' best review of the literature, no previous empirical web-store model takes repurchase (rate or pattern) as its final dependent variable, going only as far as behavioural intentions to repurchase. This has been confirmed in a recent meta-analysis where the results of 150 empirical studies involving the relationship of trust with loyalty measurements were analysed [70]. Moreover, in no previous studies has the attempt been made to offer a multi-item approach to enhance the validity and reliability of repurchase pattern measurement, assessing it as a dimension and not merely as a single-item variable. According to an empirical study by [30], a multi-item scale can be a more valid and stable measurement technique than a singleitem measurement for the assessment of a specific construct. This is thanks to the multiple cross-confirmation between the various indicators for a given latent variable. Therefore, to test this model and its supporting hypotheses empirically, a structural equation model was developed with data gathered from a sample of web-store shoppers. Thus, conclusions, implications, limitations and new research proposals are discussed.

This study is structured as follows. First, a conceptual framework is offered in which a series of rationalizations are presented to propose a system of hypotheses, relating different constructs. This system of hypotheses taken together constitutes a conceptual model designed to explain the purchase behaviour of customers in a web-store. In order to test these hypotheses, an empirical methodology is proposed. Measurements for a structured questionnaire are also presented, and the results regarding their reliability and validity are shown. The statistical results are then presented in the form of a path SEM model, in which the coefficients of the fit indexes of the statistical model are analysed, and the relationship between the latent variables are deliberated in order to weather-support the hypotheses. Conclusions are then discussed. Lastly, limitations of the study and propositions for future research are outlined.

\section{Conceptual Framework}

In the following lines, a conceptual framework is developed linking the hypotheses that support the model schematized in Figure 1. For the assessment of web-store quality, an adapted four-dimensional approach is taken. This approach is partially based on the four phases of a consumer's online shopping experience proposed by [124]. These phases outline the process that a customer commonly follows to make a purchase in a web-store, and constitute the source from which the current conceptual framework was developed and the proposed model was conjectured. Nevertheless, a thorough examination was also made of other web-store quality measurement scales to determine the specific measurements used in the current study. Definitions of the constructs involved in this model are shown in Table 1 as conceptualized for the current study. 


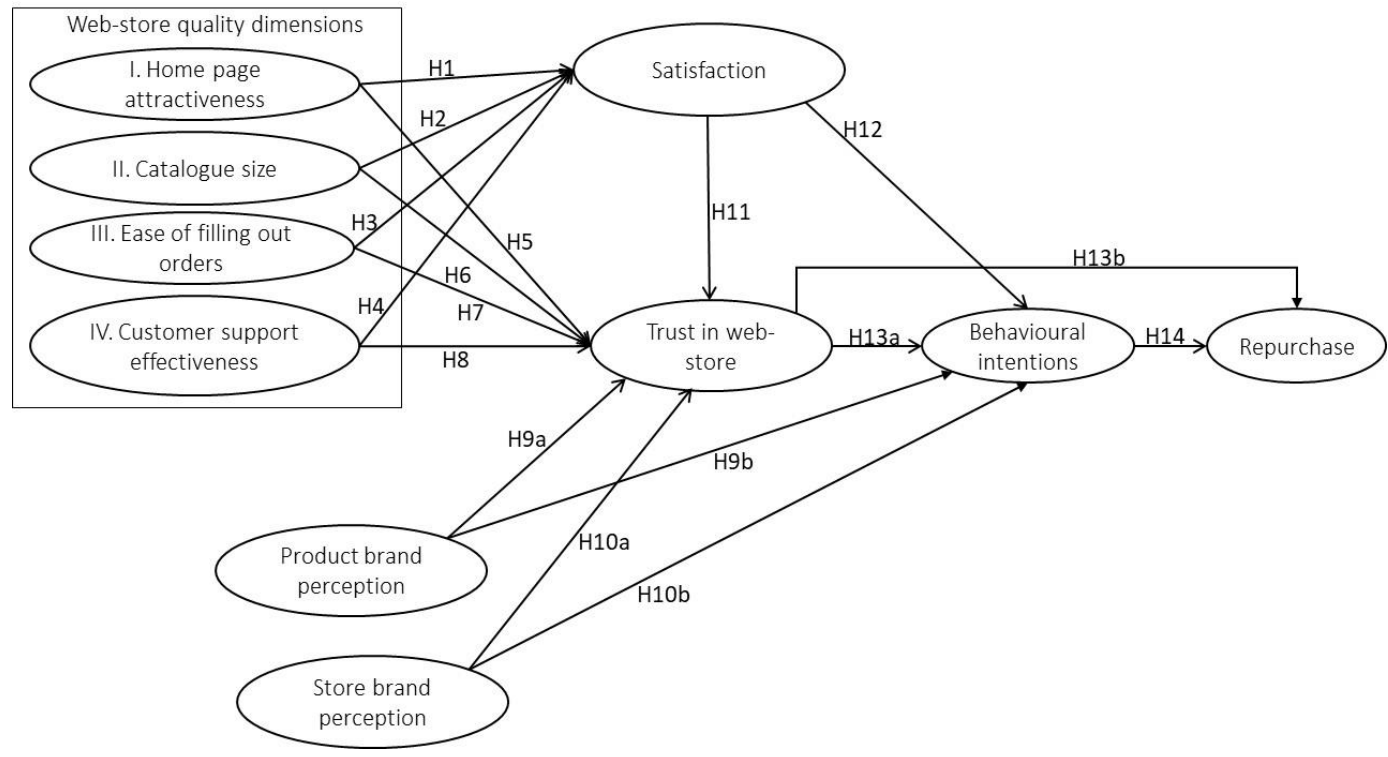

Figure 1: Conceptual Framework and hypotheses

Table 1: Constructs and dimensions

\begin{tabular}{|c|c|c|}
\hline Construct/dimension & Definition & Adapted from \\
\hline Web-store quality & $\begin{array}{l}\text { The perceived extent to which a web site facilitates efficient and } \\
\text { effective shopping, purchasing and delivery, including information } \\
\text { search, navigation, order form, interactions and delivery. }\end{array}$ & [135], [146] \\
\hline $\begin{array}{l}\text { Home page } \\
\text { attractiveness }\end{array}$ & $\begin{array}{l}\text { Visual appeal and image, interactivity, and web innovativeness that } \\
\text { can reflect the value proposition. }\end{array}$ & $\begin{array}{l}\text { [50], [60], [61], } \\
{[73]}\end{array}$ \\
\hline $\begin{array}{l}\text { Product catalogue } \\
\text { size }\end{array}$ & $\begin{array}{l}\text { The wide range of products and brands within the product } \\
\text { categories offered that enable the web-store to differentiate itself } \\
\text { through the variety offered to customers. }\end{array}$ & [2], [49], [120], \\
\hline $\begin{array}{l}\text { Ease of filling out } \\
\text { order form }\end{array}$ & $\begin{array}{l}\text { The degree to which the layout of the order form is self-explanatory } \\
\text { so that online operations may be completed promptly without } \\
\text { problems. }\end{array}$ & [83] \\
\hline $\begin{array}{l}\text { Customer support } \\
\text { effectiveness }\end{array}$ & $\begin{array}{l}\text { The ability to provide customers with quick and effective responses } \\
\text { to questions or queries concerning purchases, while transmitting } \\
\text { sincere interest in customer needs. }\end{array}$ & [47], [83] \\
\hline $\begin{array}{l}\text { Product brand } \\
\text { perception }\end{array}$ & $\begin{array}{l}\text { Cognitive associations with the brands of the products that are } \\
\text { offered with promises of fulfilment based on reputation and previous } \\
\text { experiences. }\end{array}$ & [63], [100] \\
\hline $\begin{array}{l}\text { Store brand } \\
\text { perception }\end{array}$ & $\begin{array}{l}\text { Cognitive associations with the name and logo of the store with the } \\
\text { promise of delivery based on reputation and previous experience as } \\
\text { indication of quality and value added. }\end{array}$ & [54], [109] \\
\hline Satisfaction & $\begin{array}{l}\text { A post-purchase assessment and affective response to the overall } \\
\text { service experience, based on previous encounters. }\end{array}$ & [4], [37], [82] \\
\hline $\begin{array}{l}\text { Trust in the web- } \\
\text { store }\end{array}$ & $\begin{array}{l}\text { The perception held by the consumer that the service provider is } \\
\text { dependable and can be relied upon to deliver on its promises. }\end{array}$ & $\begin{array}{l}{[3],[18],[85]} \\
{[89],[110]} \\
{[119]}\end{array}$ \\
\hline $\begin{array}{l}\text { Behavioural } \\
\text { intentions }\end{array}$ & $\begin{array}{l}\text { The consumer's commitment to consistently purchase a brand, and, } \\
\text { in this case, to visit a brand store, because of a personal preference. }\end{array}$ & $\begin{array}{l}\text { [23], [24], [26], } \\
{[36],[75],[97],} \\
{[117]}\end{array}$ \\
\hline Repurchase pattern & $\begin{array}{l}\text { The actual purchase rate or frequency of purchasing behaviour (or } \\
\text { purchasing pattern) of a given brand within a particular category (in } \\
\text { this case within the same store brand). }\end{array}$ & $\begin{array}{l}{[98],[116]} \\
{[129]}\end{array}$ \\
\hline
\end{tabular}

A significant number of web shoppers abandon their transactions due to websites with poor performance [88]. [25] found that satisfaction has a significant mediating effect between online service quality and loyalty. Website quality is considered an important antecedent of satisfaction [139]. Aspects such as accessibility, information quality and userfriendliness are likely to have positive repercussions on the level of consumer website satisfaction. According to [111], dimensions such as ease of use, e-scape, responsiveness, customer engagement and customization indirectly influence online loyalty through satisfaction. Homepages are gateways to major resources; when these pages are free of accessibility errors, they provide successful pathways to other information [142]. Thus, the homepage is likely to be 
understood as an indicator of the accessibility to the entire website [48]. Therefore, website design is of great importance for achieving overall user satisfaction, and thus affects customer purchase decisions [25], [65].

\section{H1: Home page attractiveness has a positive effect on customer satisfaction in a web-store purchase.}

Once a customer has engaged with the homepage, the challenge is to provide an engaging product catalogue that can increase the customer's interest in finding the product that matches her/his needs.

[136] proposed that availability of information is one of the most important aspects of online purchasing. Therefore, an important benefit for Internet users is the reduction in search costs, especially for product information [7], [8]. The potentially larger range of products has been identified as an advantage of web shopping over traditional stores [71]. Some evidence shows that a larger coverage of products and information in the catalogue of a web-store that offers more options may attract more clients [32], [83], [123], [137]. Thus, an ample range of products and well-organized information is mentioned frequently by customers as a major factor in customer satisfaction [25], [77] and in web-store purchasing [136]. Hence:

\section{H2: Catalogue size has a positive effect on customer satisfaction in a web-store purchase.}

Once the customer has chosen a product in the web-store, filling out the order form should be easy enough to ensure placement of the order. Certain key elements of information exchanges between a web-store and the customer are likely to have a positive effect on confidence, satisfaction and purchase intention [104]. Specifically, it has been found that effectiveness in order management is an important antecedent of consumer satisfaction [135]. [101] indicate that order fulfilment management is an influential factor in perceived quality and loyalty. Thus, ease of filling orders has been conceptually suggested as an important predictor of online satisfaction [124]. Therefore:

H3: Ease of filling out orders has a positive effect on the satisfaction that the customer experiences when purchasing in a web-store.

Once the order form has been submitted, the next issue is how the web-store can make a good impression in terms of service and support up until the customer receives his order. Common complaints online refer to confusing business rules, unsatisfactory delivery issues, product failure, problems with after-sales service and payment/billing issues [19]. Both the form of the unpleasant experience and the way the company handles the complaint, are likely to affect future online purchase intentions [35], [105], [106] and thus could determine the growth of an online retailer [15], [105], [106]. Customers expect to be able to complete transactions correctly, to have products delivered on time and to receive prompt information [25]. Customer satisfaction with online stores may drive repeat purchases, but when customers encounter undesirable purchase-related experiences, they are likely to become dissatisfied [15], [17], [28], [105], [106] and to complaint [17], [20], [58], [78]. Consequently, concern for the customer has been considered one of the most important drivers of online service satisfaction [103], [127], [134], [138]. Therefore:

H4: Customer support effectiveness has a positive effect on the satisfaction the customer experiences when purchasing in a web-store.

[46] proposed a set of brand trust antecedents that can strengthen the effect of trust-assuring arguments in a webstore: security, privacy, brand name, word-of-mouth, online experience and information quality. [94] propose that trust exists when one party has confidence in an exchange partner's reliability and integrity. Moreover, [93] define trust as a willingness to rely on an exchange partner in whom one has confidence. In addition, [62] stress the importance of website design and provide guidelines for creating a favourable store image. Therefore, a virtual shopping environment with a favourable store image may effectively encourage transactions and help build trust [62]. Thus, home page attributes can lead to customer trust in a website [72]. Consequently:

\section{H5: Home page attractiveness has a positive effect on the customer's trust in a web-store.}

An online commerce web site can attract more customers by providing multiple product options with complete information [32], [137]. A wider assortment of products in a web-store may be attractive to customers [83], [123]. The product catalogue has been identified as an advantage of web shopping, as it can offer a wider variety of products than a physical store [71]. Good search results for the customer can help to increase customer trust in a web-store [41]. As there is a larger product catalogue offering more options to the customer, it is likely to obtain better and more focused search results. Hence:

\section{H6: Catalogue size has a positive effect on customer trust in a web-store.}

Even though a user-friendly catalogue is likely to foster customer intentions, filling out the order form can inhibit purchase finalization. A secure and safe transaction is likely to be a major factor in an online company's perceived reliability [64]. Ease of use of a technological system that can provide a stress-free online buying experience can save customer's time and in part reflects the convenience of online shopping [83]. Therefore, order management effectiveness carries considerable weight in the assessment of a commercial service [69], [84], [135]. Thus, a website 
is likely to foster negative attitudes when there are billing and payment difficulties and complex delivery arrangements [74]. Accordingly:

\section{H7: Ease of filling out order forms has a positive effect on customer trust in a web-store.}

Once the order form has been submitted, the customer has to wait for the product to arrive. The buyer may be anxious due to online shopping factors such as the exchange policy and possible additional charges and delivery among other things [13]. When encountering a problem, customers may expect a rapid response from sellers [139]. Accurate support from the store to customers in terms of rapidness, concrete answers and clear solutions to requests can become important for online commerce, considering the absence of a physical store and face-to-face salespeople who can provide guidance and answer complaints [139]. Responsiveness refers to the online retailer's commitment to provide rapid feedback and is generally associated with receptivity to customer needs [29]. Thus, interactivity and responsiveness tend to favour trust development [21], [139]. Therefore:

\section{H8: Customer support effectiveness has a positive effect on customer trust in a web-store.}

Since customers purchasing through a website do not have personal contact with a retailer, they may depend on their trust in the offered brands [41]. Certain product brands may invoke such levels of trust in the customer that a spill-over effect can occur, benefitting the retailer and its website [143]. If retailers can create a connection in the minds of consumers with the brands they carry, they can likely benefit from this association [143]. Therefore, it is in the best interest of retailers to bolster customer perception of the brands they offer [143]. By working together, both manufacturers and retailers can benefit from each other's brands [131]. Thus, retailers may be able to increase trust in the web-store by carrying strong brands [143], and reap a number of benefits including image enhancement and pre-established demand [131]. Hence:

H9a: Product brand perception has a positive effect on consumer trust in a web-store.

H9b: Product brand perception has a positive effect on behavioural intentions in a web-store.

While the product catalogue plays a significant role, it has been found that the store as a brand could turn out to be as important [90]. The corporate image of the store can be defined as a combination of the store as a brand with the store brands and manufacturer brands offered by the store [43]. A positive online store image favours customer satisfaction and store loyalty [10], [90]. A favourable brand image tends to have a positive effect on relevant outcomes, such as premium price capability and positive word-of-mouth [10], [99]. In clothing markets, customers tend to be sensitive to store brand personality, suggesting that the image of the store can make a difference [41]. Thus, a strong store image offers recognition, familiarity, confidence and other associations that make it easier for customers to build trust [31]. Therefore:

H10a: Brand store perception has a positive effect on customer trust in a web-store.

H10b: Brand store perception has a positive effect on behavioural intentions in a web-store.

Customer satisfaction is a cumulative global evaluation based on experience with a firm over time [53]. It has been found that satisfaction can be an antecedent of trust [39]. Similar results have been found in retail settings [11], and proposed as well in services [118]. Trust is a complex phenomenon with important implications for online commerce [6], [40]. Some researchers have suggested that trust is likely the most significant factor of success in an online environment [73], [115]. It has been suggested that satisfaction has a direct effect on customer trust in online commerce [102]. Hence:

\section{H11: Satisfaction has a positive effect on customer trust in a web-store.}

In general, satisfaction may lead to customer loyalty [91], [113]. In turn, satisfaction and loyalty may help to achieve a stronger competitive position for the brand and a higher market share [37]. Thus, satisfaction is a key antecedent of loyalty measurements such as revisiting the store, re-purchasing in the store and giving favourable word-of-mouth [4], [38], [145]. Nevertheless, good web-store quality does not always result in repurchases when customers have more satisfying experiences elsewhere [77]. Given that customer satisfaction captures past behaviour as an evaluative summary of consumption experiences, it is likely that it has a direct effect on consumer intentions [112], [121]. Hence:

\section{H12: Satisfaction has a positive effect on customer behavioural intentions in a web-store.}

Trust in web-stores includes incorporating security elements, guaranteeing confidentiality and conveying a reliable image [25]. The lack of confidence caused by the absence of security and privacy is considered a major obstacle to online commerce development [84], [135]. Online buyer confidence tends to be reinforced by the ability of online sellers to assess and fulfil customer needs and expectations [128]. Thus, online customers prefer to make their purchases from websites they trust [59]. This is because trust can reduce buyer uncertainty [5]. Therefore, trust tends to encourage loyalty in an Internet environment [111], constituting a stronger antecedent of behavioural intentions than 
other variables, such as customer-perceived value and perceived price level [66], [122]. Furthermore, some suggest that trust overcomes satisfaction as the dominant antecedent of repurchase intentions [21], [70], [82]. Therefore:

H13a: Trust in a web-store has a positive effect on behavioural intentions.

H13b: Trust in a web-store has a positive effect on repurchase patterns.

Customers do not necessarily purchase from the lowest-priced stores [107]. Non-monetary aspects, such as time and effort, are also considered in making purchase decisions [144]. Thus, customers carefully consider savings in time and effort when making on-line purchases [126]. Customer retention and repeating buyers are sources of profit because loyal customers are likely to be less sensitive to price, can be served at a lower cost and are inclined to pass on positive recommendations to others [81], [107], [108]. As convenience in Internet shopping is related to time and effort involved, customers are motivated to decide repurchases based on time savings and reduced hassles, especially for routine repurchase items [45]. Repurchase behaviour is considered an objectively observed indicator [116]. It has also been proposed that repurchase is a valid measurement of store loyalty [87], [95]. Previous literature has suggested that perceived value and behavioural intentions can lead to repurchase patterns [33], [144]. Thus, behavioural intentions have been established as an antecedent of actual loyalty [97]. Hence:

H14: Behavioural intentions in a web-store have a positive effect on repurchase patterns.

\section{Methodology}

A post-hoc study was implemented for which a structured questionnaire was designed. As latent variables were required for the data analysis, the questionnaire was designed incorporating multiple items for each construct/dimension involved in the study. Autonomous purchase decision-makers familiar with Internet shopping were required as participants. These had to be habitual web-store shoppers who had bought products for themselves with their own money, choosing themselves what to buy. Furthermore, in order to ensure that the participants had purchased from a formal web-store with service attention procedures of the type assumed in the model, it was important to recruit customers who had made regular purchases in web-stores that are well known in Mexico. Therefore, participating subjects had to possess the following characteristics: having purchased in at least one of eight selected department web-stores (Liverpool, Sears, El Palacio de Hierro, Sanborns, Best Buy, Amazon, Fabricas de Francia and Walmart) at least five times in the previous twelve months. The selected points of purchase are very well known web-stores in Mexico. A number of pilot tests were carried out in the validation process of the questionnaire. Through these pilot tests, the participants' awareness of the web-store names was tested. All the participants in these preliminary trials recognized these eight web-stores. Criteria for participation were that subjects had to have bought items for their own use, had to be in the age range of 25 to 50 and had to be residents of Mexico City. They had to like purchasing online and be holders of at least one credit card. The study does not consider business-to-business buyers. For variability control over the measurements, only department web-stores were considered. For the fieldwork, the questionnaire was uploaded to an Internet survey platform. Thus, a convenience sample of 1,540 respondents was collected. As it was an Internet survey, the intention was to keep strict control over who would participate, sending the Internet link only to those meeting participation requirements. Nevertheless, in many cases, the invitation was forwarded from respondent to respondent, entailing some loss of control over the process. Therefore, a verification of the participants was carried out in which, after careful screening, the sample was scaled down to 500 observations that met the required features mentioned above.

\section{Measurements}

For measurements of all constructs, except repurchase, seven-point Likert scales were used. Internal consistency reliability was assessed through Cronbach's alpha coefficients. Thus, internal consistency was measured unidimensionally within the items related to each construct or dimension established in the conceptual framework. To complement reliability assessment, average variance extracted and composite reliability were also calculated following this same fashion. As can be seen in Table 2, highly acceptable reliability coefficients above .8 and .9 were obtained in all cases, except for the measurements of repurchase. According to [42] p.231, [27] p.53, and to [133], an alpha coefficient above .9 is considered an indicator of excellent internal consistency.

To verify the convergent and discriminant validity of the items, a principal component (factorial) analysis with oblique (non-orthogonal) rotation was carried out. Oblique rotation was used, as some interdependency between latent variables was expected and therefore between components as well (see Appendix 1). A clear convergence in a single statistical component (factor) of the items related to the corresponding construct or dimension was confirmed (except for repurchase) with factorial loadings above .6 and up to .9 or higher. Discrimination between items for the different constructs in different factors also was observed in almost all cases, although, as expected, there is some correlation between some of the latent variables (dimensions or constructs). There cannot be full discrimination or independence, as relationships in this analysis are expected to form among some of these variables, as is expected to occur with the relationships proposed in the hypotheses. For this factorial analysis, a Kaiser-Meyer-Olkin (KMO) coefficient of .95 
and a significant Bartlett coefficient show a good fit of the data to the model, where the factorial solution can be interpreted as the adequate representation of the observed variables [34], [125].

Table 2: Items, alpha internal reliability $(\alpha)$, average variance extracted (ave), and composite reliability (cr)

\begin{tabular}{|c|c|c|c|c|c|}
\hline Construct & $\alpha$ & ave & $\mathrm{cr}$ & Items (translations from Spanish) & $\begin{array}{l}\text { Adapted } \\
\text { from }\end{array}$ \\
\hline $\begin{array}{l}\text { Home page } \\
\text { attractiveness }\end{array}$ & .94 & .85 & .96 & $\begin{array}{l}\text { The homepage of the web-store is very attractive } \\
\text { The design of this web-store looks professional } \\
\text { The homepage is of high quality } \\
\text { I like the appearance of the homepage of this web-store }\end{array}$ & $\begin{array}{l}{[18],[84],} \\
{[132],[138],} \\
{[140]}\end{array}$ \\
\hline $\begin{array}{l}\text { Product } \\
\text { catalogue } \\
\text { size }\end{array}$ & .97 & .91 & .98 & $\begin{array}{l}\text { The web-store offers a wide line of products } \\
\text { The web-store offers a good selection of products } \\
\text { The web-store offers a complete range of products } \\
\text { In this web-store there is a great variety of products }\end{array}$ & $\begin{array}{l}{[12],[41],} \\
{[44],[132]} \\
{[140]}\end{array}$ \\
\hline Order form & .97 & .92 & .97 & $\begin{array}{l}\text { The web-store facilitates the process of filling out the } \\
\text { purchase order } \\
\text { It is very easy to generate a purchase order in this web- } \\
\text { store } \\
\text { I have no difficulty filling in the information required by the } \\
\text { web-store }\end{array}$ & $\begin{array}{l}\text { [1], [22], } \\
{[76]}\end{array}$ \\
\hline $\begin{array}{l}\text { Customer } \\
\text { support }\end{array}$ & .94 & .90 & .96 & $\begin{array}{l}\text { When a problem arises, the web-store shows a sincere } \\
\text { interest in solving it } \\
\text { Complaints are answered quickly by the web-store } \\
\text { Customer support for this online store is easily accessible }\end{array}$ & $\begin{array}{l}\text { [18], [47], } \\
\text { [83], [67] }\end{array}$ \\
\hline Satisfaction & .96 & .94 & .98 & $\begin{array}{l}\text { The service in the web-store is excellent } \\
\text { I am very satisfied with my shopping experience at this } \\
\text { web-store } \\
\text { The web-store meets my expectations }\end{array}$ & $\begin{array}{l}\text { [22], [44], } \\
{[47],[67],} \\
{[132]}\end{array}$ \\
\hline $\begin{array}{l}\text { Trust on the } \\
\text { web-store }\end{array}$ & .97 & .94 & .98 & $\begin{array}{l}\text { This web-store protects my credit card details } \\
\text { I feel secure in the transactions I make in this web-store } \\
\text { This web-store protects my privacy }\end{array}$ & $\begin{array}{l}\text { [22], [44], } \\
{[47],[67],} \\
{[114],[132]}\end{array}$ \\
\hline $\begin{array}{l}\text { Products } \\
\text { brand } \\
\text { perception }\end{array}$ & .97 & .93 & .98 & $\begin{array}{l}\text { This web-store offers products from well-known brands } \\
\text { This web-store offers products from leading brands } \\
\text { This web-store offers reliable brand products }\end{array}$ & $\begin{array}{l}\text { [41], [44], } \\
{[143]}\end{array}$ \\
\hline $\begin{array}{l}\text { Brand store } \\
\text { perception }\end{array}$ & .97 & .94 & .98 & $\begin{array}{l}\text { The brand of this web-store has a good reputation } \\
\text { The brand of this web-store is recognized } \\
\text { The brand of this web-store is reliable }\end{array}$ & [116], [143] \\
\hline $\begin{array}{l}\text { Behavioural } \\
\text { intentions }\end{array}$ & .97 & .90 & .97 & $\begin{array}{l}\text { If I had to, I would buy again from this online store } \\
\text { I would use this online store again to meet my needs } \\
\text { For future purchases this online store is recommendable } \\
\text { I will buy again from this online store }\end{array}$ & $\begin{array}{l}\text { [12], [22], } \\
{[44],[132]}\end{array}$ \\
\hline $\begin{array}{l}\text { Repurchase } \\
\text { pattern }\end{array}$ & .06 & .32 & .43 & $\begin{array}{l}\text { Transactions made in this web-store in the last twelve } \\
\text { months } \div \text { total web-store transactions made in all web- } \\
\text { stores in the last twelve months. } \\
\text { Of the total online transactions, what percentage has been } \\
\text { in this web-store? } \\
\text { How many times have you bought something in this web- } \\
\text { store? } \\
\text { I buy frequently in this online store }\end{array}$ & $\begin{array}{l}\text { [98], [116], } \\
{[129]}\end{array}$ \\
\hline
\end{tabular}

As stated above, one of the differentiators of this study, in contrast to previous ones, is that the intention of the current web-store purchase behavioural model is not only to explain behavioural intentions, but also to assess repurchase pattern as the final dependent variable, giving the study more internal validity. The intention is thus not only to include a single observed variable indicator for repurchase, but also to propose a multi-item measurement for this variable, which has never been attempted before in this kind of study. Regrettably, under the reliability and validity tests, the results were not as good as those shown above for the other variables. Nevertheless, this multi-item approach for repurchase was retained for two reasons. First, in the structural equation model used to test the hypotheses, the observed variables used for the repurchase latent variable showed statistically significant measurement weights (Table 3). The measurement weights between a latent variable and observed variables in a structural equation model can constitute a rigorous alternative method of confirming convergence validity of the items and construct reliability for the latent variable [57]. Second, as mentioned above, this approach was considered worth keeping because of the innovative introduction of a multi-item measurement for this variable. As noted above, this form of measurement can outperform single-item measurement in terms of reliability and stability [30]. While this problem is acknowledged as one of the limitations of the study, the multi-item approach is nevertheless retained here to emphasize the need for further research into improving multi-item measurement of customer repurchase patterns. 


\section{Results}

The demographic composition of the obtained sample $(n=500)$ is as follows. Purchasers by web-store in México: Sanborns $0.4 \%$, Sears 1.2\%, Liverpool 34.6\%, Fabricas de Francia 0.4\%, Amazon 45\%, Bestbuy 4.4\%, Palacio de Hierro 3\% and Walmart 8\%. Gender: male 58\%, female 42\%. Age (in years): 25 to 33, 58\%, 34 to 42, 31\% and 43 to $50,11 \%$. Number of cars they possess in the family: 0 or $1,36 \%, 2$ or $3,49 \%$ and 4 or more, $15 \%$. Number of credit cards they have: 1 or $2,67 \%, 3$ or $4,22 \%$ and 5 or more, $11 \%$. Inshore (domestic) travels for pleasure per year: 0 or $1,61 \%, 2$ or $3,30 \%$ and 4 or more, $9 \%$. Offshore (international) travels for pleasure per year: $85 \%$ of the respondents did not report offshore travels, 1 per year, $11 \%, 2$ or more, $4 \%$. A correlation matrix between variables is presented in Appendix 1.

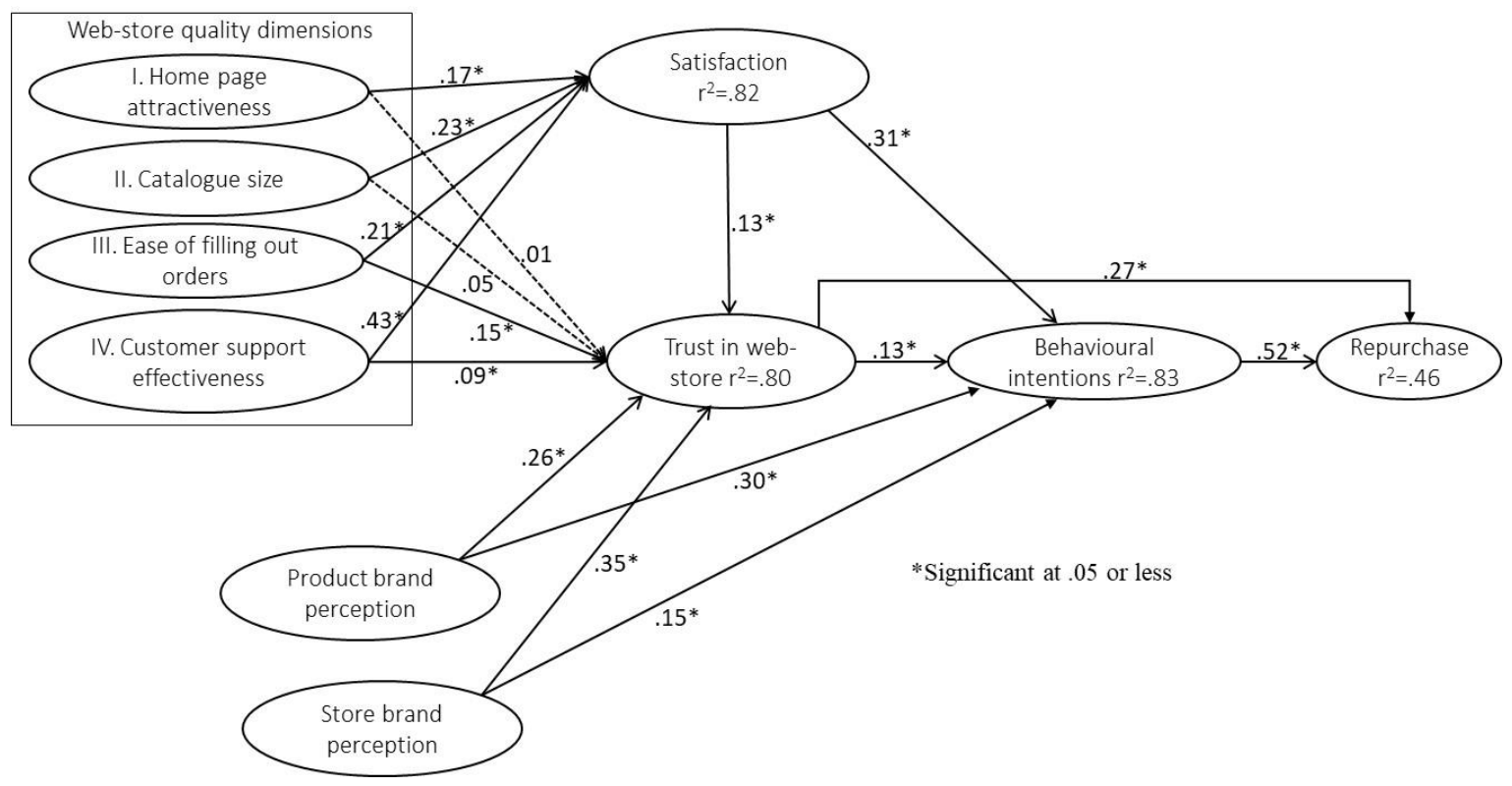

Figure 2: Statistical model and coefficients

Table 3: Standardized measurement weights

\begin{tabular}{|c|c|c|c|c|}
\hline $\begin{array}{l}\text { Observed } \\
\text { variable }\end{array}$ & & Latent variable & Estimate & p-value \\
\hline Homep3 & $\leftarrow$ & HomeP & .923 & \\
\hline Homep2 & $\leftarrow$ & HomeP & .888 & $\star \star \star *$ \\
\hline Homep1 & $\leftarrow$ & HomeP & .880 & 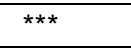 \\
\hline Homep4 & $\leftarrow$ & HomeP & .885 & $* * *$ \\
\hline ProdC3 & $\leftarrow$ & ProdC & .934 & $* * *$ \\
\hline ProdC2 & $\leftarrow$ & ProdC & .958 & $\star \star * \star$ \\
\hline ProdC1 & $\leftarrow$ & ProdC & .950 & $* * *$ \\
\hline ProdC4 & $\leftarrow$ & ProdC & .920 & $* * *$ \\
\hline OrdF4 & $\leftarrow$ & OrderForm & .950 & $* * *$ \\
\hline OrdF3 & $\leftarrow$ & OrderForm & .990 & $* \star * \star$ \\
\hline OrdF2 & $\leftarrow$ & OrderForm & .928 & $\star * \star$ \\
\hline CustS4 & $\leftarrow$ & CustSupport & .886 & $\star \star \star *$ \\
\hline CustS3 & $\leftarrow$ & CustSupport & .949 & 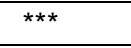 \\
\hline CustS2 & $\leftarrow$ & CustSupport & .923 & $\star * *$ \\
\hline Satisf1 & $\leftarrow$ & Satisf & .929 & 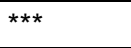 \\
\hline Satisf3 & $\leftarrow$ & Satisf & .974 & $\star \star \star *$ \\
\hline Satisf4 & $\leftarrow$ & Satisf & .964 & $* * *$ \\
\hline PBP4 & $\leftarrow$ & ProdBrandPerc & .933 & 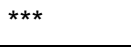 \\
\hline PBP3 & $\leftarrow$ & ProdBrandPerc & .956 & $\star \star \star *$ \\
\hline PBP2 & $\leftarrow$ & ProdBrandPerc & .958 & 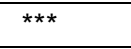 \\
\hline
\end{tabular}




\begin{tabular}{|c|c|c|c|c|}
\hline \multicolumn{5}{|c|}{ Table 3: continuation } \\
\hline BSP2 & $\leftarrow$ & BrandStorePerc & .936 & *** \\
\hline BSP1 & $\leftarrow$ & BrandStorePerc & .960 & *** \\
\hline BSP3 & $\leftarrow$ & BrandStorePerc & .976 & 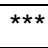 \\
\hline Blnt1 & $\leftarrow$ & Behavint & .937 & 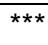 \\
\hline BInt4 & $\leftarrow$ & Behavint & .894 & *** \\
\hline BInt5 & $\leftarrow$ & Behavint & .943 & *** \\
\hline BInt2 & $\leftarrow$ & Behavioural Int. & .960 & 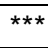 \\
\hline Trust2 & $\leftarrow$ & Trust & .951 & $\star * *$ \\
\hline Trust1 & $\leftarrow$ & Trust & .976 & 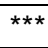 \\
\hline Trust4 & $\leftarrow$ & Trust & .924 & *** \\
\hline Repu3 & $\leftarrow$ & Repurchase & 1.050 & * \\
\hline Repu2 & $\leftarrow$ & Repurchase & .129 & * \\
\hline Repu1 & $\leftarrow$ & Repurchase & -.096 & * \\
\hline Repu4 & $\leftarrow$ & Repurchase & .125 & * \\
\hline
\end{tabular}

As mentioned before, a statistical structural equations model was constructed to test the hypotheses and thus the conceptual model. In Figure 2, a schematization of the resulting model is presented. With this structural equation model, acceptable values of absolute fit indexes were obtained with a CMIN/DF (chi-square minimum discrepancy divided by its degrees of freedom) value of 3.93 and a RMSEA (root mean square error of approximation) value of .08. According to [133] CMIN/DF must be lower than 5.0 for there to be a proper fit of the data with the model. According to [86] a value of about 0.9 or less for the RMSEA would indicate an acceptable error of approximation of the model with the data. As for relative (or baseline comparison) fit indexes, the model displayed acceptable values of $\mathrm{NFI}$ (normed fit index)=.92, RFI(relative fit index)=.91, IFI(incremental fit index)=.94, TLI(non-normed fit index)=.93 and $\mathrm{CFI}$ (comparative fit index)=.94. According to [56], relative fit index values must be greater than .90 to establish an appropriate fit between the obtained model and a perfect baseline model.

Regarding measurement indicators for the latent variables in this structural model, almost all the measurement weights between observed variables and their corresponding latent variables were high (close to 1) and statistically significant, showing an acceptable assessment of the latent variables representing the constructs in the current conceptual model. Even for repurchase, measurement weights were low but statistically significant, as previously stated. Standardized measurement weights and regression weights are shown in Table 3.

Table 4: Regression weights between latent variables

\begin{tabular}{|c|c|c|c|c|}
\hline Hypothesis & Independent V. & Dependent V. & $\begin{array}{l}\text { Regression } \\
\text { weight }\end{array}$ & Decision \\
\hline $\mathrm{H} 1$ & Home page & $\rightarrow$ Satisfaction & $.17^{\star \star \star}$ & Accept \\
\hline $\mathrm{H} 2$ & Catalogue & $\rightarrow$ Satisfaction & $.23^{\star \star \star}$ & Accept \\
\hline $\mathrm{H} 3$ & Order form & $\rightarrow$ Satisfaction & $.21^{\star \star \star}$ & Accept \\
\hline $\mathrm{H} 4$ & Customer support & $\rightarrow$ Satisfaction & $.43^{\star \star \star}$ & Accept \\
\hline $\mathrm{H} 5$ & Home page & $\rightarrow$ Trust & .01 & Reject \\
\hline $\mathrm{H} 6$ & Catalogue & $\rightarrow$ Trust & .04 & Reject \\
\hline $\mathrm{H} 7$ & Order form & $\rightarrow$ Trust & $.15^{\star \star \star}$ & Accept \\
\hline $\mathrm{H} 8$ & Customer support & $\rightarrow$ Trust & $.09^{*}$ & Accept \\
\hline $\mathrm{H} 9 \mathrm{a}$ & Product brand & $\rightarrow$ Trust & $.26^{\star \star \star}$ & Accept \\
\hline $\mathrm{H} 9 \mathrm{~b}$ & Product brand & $\rightarrow$ Intentions & $.30^{\star \star \star}$ & Accept \\
\hline $\mathrm{H} 10 \mathrm{a}$ & Brand store & $\rightarrow$ Trust & $.35^{\star \star \star}$ & Accept \\
\hline $\mathrm{H} 10 \mathrm{~b}$ & Brand store & $\rightarrow$ Intentions & $.15^{\star \star}$ & Accept \\
\hline $\mathrm{H} 11$ & Satisfaction & $\rightarrow$ Trust & $.13^{\star \star}$ & Accept \\
\hline $\mathrm{H} 12$ & Satisfaction & $\rightarrow$ Intentions & $.31^{\star \star \star}$ & Accept \\
\hline $\mathrm{H} 13 \mathrm{a}$ & Trust & $\rightarrow$ Intentions & $.13^{\star \star}$ & Accept \\
\hline $\mathrm{H} 13 \mathrm{~b}$ & Trust & $\rightarrow$ Repurchase & $.27^{\star \star \star}$ & Accept \\
\hline $\mathrm{H} 14$ & Intentions & $\rightarrow$ Repurchase & $.52^{\star \star \star}$ & Accept \\
\hline
\end{tabular}

As hypothesized in the conceptual model, the standardized regression weights between latent variables are statistically significant (except between home page attractiveness and trust, and between product catalogue size and trust), as shown in Table 4. Although these coefficients are not very high, the combined explanatory effect of the independent variables and the mediating variables allow for a considerable level of determination of the dependent variables in this structural equation model. Therefore, as presented in Table 5, squared multiple correlations for dependent variables are above .80 for satisfaction, trust and behavioural intentions, showing a determination level of more than $80 \%$ of the 
structural model for these variables. Even for the repurchase dependent latent variable, there is an interesting level of statistical determination (46\%), given that according to [97] behavioural loyalty is the most difficult dimension of loyalty to predict. To confirm the results, the statistical model was tested without the non-significant regression weights (home page attractiveness and trust; product catalogue size and trust). The results and coefficients for all the indicators were the same as those stated above: fit indexes, measurement weights, regression weights and squared multiple correlations.

Table 5: Squared multiple correlation of dependent latent variables

\begin{tabular}{|l|l|}
\hline Latent variable & R squared \\
\hline Satisfaction & .82 \\
\hline Trust & .80 \\
\hline Behavioural intentions & .83 \\
\hline Repurchase & .46 \\
\hline
\end{tabular}

\section{Conclusions and Discussion}

Consistently with the findings of [68], [130], the results suggest that home page attractiveness has a direct effect on satisfaction, contradicting [69], who claimed that web appearance has little impact on customer satisfaction. While [14], [80] assert a relationship between home page attractiveness and trust in the web-store, the present study was unable to support this relationship. Nevertheless, it may receive support indirectly through satisfaction, although the obtained indirect effects are very low, near zero. The present study supports the direct effect of product catalogue size on satisfaction, in line with [83], [120], who assume that satisfaction is higher when online stores offer superior product selection. However, a direct relationship between product catalogue size and trust in the web-store was not supported. While this relationship may receive some support indirectly through satisfaction, the obtained indirect effect tends to zero.

Ease of filling out the order form was shown to have a direct influence on satisfaction, as noted in [55], [69]. Also, a direct relationship between ease of filling out the order form and trust in the web-store was supported, as proposed by [52], which makes sense given that this attribute enables transaction capability, secure and convenient payment and the safe completion of all online shopping operations. Customer support effectiveness showed a direct relationship with satisfaction, as shown in [96], [135]. Accordingly, a direct relationship between customer support effectiveness and trust in the web-store was supported, as anticipated by [25], [101]. Thus, prompt delivery and prompt response to customer concerns appear to be a relevant group of variables in virtual shopping, as do privacy and security.

Product brand perception is how a customer tends to assess the quality of the product catalogue of a web-store. The literature review for this study shows that very little has been published on web-store product brand perception. In light of the current findings, it may be suggested that web-store product brand perception is likely to have a direct effect on trust, consistently with what had been previously found for physical stores. On the one hand there are the product brands; on the other hand, there is the web-store's name. The attractiveness of a store name, as a brand, has been found to be closely associated with three factors: the store's relationship with its customers, the pleasure of shopping in the store and how well the store understands its customers as evidenced by the selection it offers [90]. Therefore, the present study supports the claim that store brand perceptions can have a direct effect on trust and on behavioural intentions towards the web-store, as per [9], [141]. As for trust in the web-store, this was found to have a direct relationship with behavioural intentions towards a web-store, as previously noted by [16], [85].

A novel contribution of this study has been to adduce evidence that trust and intentions can have an effect on repurchase in the context of web-stores. The relevancy of this is that previous models only have purchase intentions as the final dependent variable. Purchase intentions constitute an attitudinal measurement but not a measurement of an actual observable behaviour as repurchase does. In a previous study [95], elements of a web-store have been related positively to an actual behaviour, such as client expenditure, but not to actual repurchase patterns. As stated above, this can be confirmed in a recent meta-analysis [70]. Linking the entire model to measurements of action loyalty as a final dependent variable has a high theoretical and practical relevancy. Establishing the relationship of action loyalty with previous phases of loyalty (such as intentions and attitude) encompasses the full range of loyalty phases proposed by [97], yielding a more holistic assessment of this construct. Moreover, client repurchase patterns can be considered a relevant indicator of the success of a web-store, as there is evidence linking measurements of action loyalty with business profitability [51]. As another novel contribution, it has been found that linking brand perceptions to trust and repurchase in a web-store context has a relevant managerial implication. Risk averse customers tend to show a higher and longer- lasting propensity to brand loyalty [91]. A set of strong brand perceptions associated with the name of the web-store can help to increase customer trust. Therefore, building these can facilitate the attraction of risk-averse customers, who offer a better chance of building a long-term relationship with long-term repurchase patterns. 


\section{Limitations and Future Research}

Although it was required for interviewees to have purchased products for themselves, it is important to mention that there were no specific product categories required for participation in the study. It is therefore suggested that further research focus on specific product categories to deepen knowledge of how involvement with specific product categories affects web-store perception. Additionally, testing this kind of model with a specific product category may help to reduce statistical variability, thereby helping to increase the statistical associations between variables.

As multi-item scales can have higher validity than single-item measurements [30] , a challenging part of the present research was to propose and design a valid multi-item measurement of repurchase. Even though the measurement weights of the observed variables for the repurchase latent variable are all significant, these measurement weights are low (and the alpha coefficients are unacceptable). Thus, there is still work to do to find appropriate measurements to ensure proper reliability and validity for this variable. Current authors believe this to be worthwhile as almost all published empirical purchase decision models go only as far as behavioural intentions, and very few as far as singleitem repurchase measurement. In light of the lessons to be learned from this study, it may be helpful to avoid relying too much on declared repurchase rates; when the current data is analysed, it becomes apparent that consumers tend not to remember clearly how frequently they have made purchases at a specific web-store in a specific period.

As mentioned above, as this is the first time store brand perception has been included in a model to explain loyalty or repurchase in a web-store, we decided to include it as an exogenous variable in the model. We did not want to address the question of how web-store brand perception is constructed because this can be very complex, and would take the focus away from the original objectives of the model and the study. However, web-store quality and product brand perception, among other factors, can indeed affect perception of the web-store brand. Hence, we believe that this is a very interesting path for future research.

\section{References}

[1] M. A. A. Al-Hawari, Does customer sociability matter? Differences in e-quality, e-satisfaction, and e-loyalty between introvert and extravert online banking users, Journal of Services Marketing, vol. 28, no. 7, pp. 538-546, 2014.

[2] W. Amaldoss and C. He, Product variety, informative advertising, and price competition, Journal of Marketing Research, vol. 47, no. 1, pp. 146-156, 2010.

[3] M. Amin, S. Rezaei and M. Abolghasemi, User satisfaction with mobile websites: the impact of perceived usefulness (PU), perceived ease of use (PEOU) and trust, Nankai Business Review International, vol. 5, no. 3, pp. 258-274, 2014.

[4] E. W. Anderson and M. W. Sullivan, The antecedents and consequences of customer satisfaction for firms, Marketing Science, vol. 12, no. 2, pp. 125-143, 1993.

[5] A. Angriawan and R. Thakur, A parsimonious model of the antecedents and consequence of online trust: An uncertainty perspective, Journal of Internet Commerce, vol. 7, no. 1, pp. 74-94, 2008.

[6] S. Ba and P. A. Pavlou, Evidence of the effect of trust building technology in electronic markets: Price premiums and buyer behavior, MIS Quarterly, vol. 26, no. 3, pp. 243-268, 2002.

[7] S. Van Baal and C. Dach, Free riding and customer retention across retailers' channels, Journal of Interactive Marketing, vol. 19, no. 2, pp. 75-85, 2005.

[8] S. Balasubramanian, R. Raghunathan and V. Mahajan, Consumers in a multichannel environment: Product utility, process utility, and channel choice, Journal of Interactive Marketing, vol. 19, no. 2, pp. 12-30, 2005.

[9] K. Basu. (2016, November) E-branding or rebranding?, The impact of e-business on global branding strategies. University of Oxford. [Online]. Available: http://eureka.sbs.ox.ac.uk/2522/

[10] J. Bloemer and K. DeRuyter, On the relations hip between s tore image, store satisfaction and s tore loyalty, European Journal of Marketing, vol. 32, no. 5, pp. 499-513, 1998.

[11] J. Bloemer and G. J. Odekerken-Schroder, Store satisfaction and store loyalty explained by customer and storerelated factors, Journal of Consumer Satisfaction, Dissatisfaction and Complaining Behavior, vol. 15, pp. 68-80, 2002.

[12] J. Carlson and A. O'Cass, Developing a framework for understanding e-service quality, its antecedents, consequences, and mediators, Managing Service Quality, vol. 21, no. 3, pp. 264-286, 2011.

[13] A.-S. Cases, Perceived risk and risk-reduction strategies in Internet shopping, The International Review of Retail, Distribution and Consumer Research, vol. 12, no. 4, pp. 375-394, 2002.

[14] M. Chae and J. Kim, What's so different about the mobile Internet?, Communications of the ACM, vol. 46, no. 12, p. 240, 2003.

[15] H. H. Chang, M. K. Lai and C. H. Hsu, Recovery of online service: Perceived justice and transaction frequency, Computers in Human Behavior, vol. 28, no. 6, pp. 2199-2208, 2012.

[16] A. Chaudhuri and M. B. Holbrook, The chain of effects from brand trust and brand affect to brand performance: The role of brand loyalty, Journal of Marketing, vol. 65, no. 2, pp. 81-93, 2001.

[17] S. Chea and M. M. Luo, Cognition, emotion, satisfaction, and post-adoption behaviors of E-service customers, Proceedings of the Annual Hawaii International Conference on System Sciences, vol. 12, no. 3, pp. 29-56, 2007. 
[18] Y. H. Chen, J. J. Wu and H. T. Chang, Examining the mediating effect of positive moods on trust repair in ecommerce, Internet Research, vol. 23, no. 3, pp. 355-371, 2013.

[19] Y. Cho, I. Im, R. Hiltz, and J. Fjermestad, An analysis of online customer complaints: Implications for Web complaint management, in Proceedings of the Annual Hawaii International Conference on System Sciences, Hawaii, 2022, pp. 2308-2317.

[20] Y. Cho, I. Im, R. Hiltz, and J. Fjermestad, The effects of post-purchase evduatim factors on customer complaining behavior: Implications for customer loyalty, Advances in Consumer Research, vol. 29, pp. 318-327, 2002.

[21] M. Chosin and A. Ghaffari, An investigation of the impact of effective factors on the success of e-commerce in small and medium-sized companies, Computers in Human Behavior, vol. 66, pp. 67-74, 2017.

[22] S. Chou, C. W. Chen and J. Y. Lin, Female online shoppers: Examining the mediating roles of e-satisfaction and e-trust on e-loyalty development, Internet Research, vol. 25, no. 4, pp. 542-561, 2015.

[23] R. Connolly and F. Bannister, Consumer trust in Internet shopping in Ireland: Towards the development of a more effective trust measurement instrument, Journal of Information Technology, vol. 22, no. 2, pp. 102-118, 2007.

[24] C. L. Corritore, B. Kracher and S. Wiedenbeck, On-line trust: Concepts, evolving themes, a model, International Journal of Human Computer Studies, vol. 58, no. 6, pp. 737-758, 2003

[25] E. Cristobal, C. Flavián and M. Guinalíu, Perceived e-service quality (PeSQ): Measurement validation and effects on consumer satisfaction and web site loyalty, Managing Service Quality, vol. 17, no. 3, pp. 317-340, 2007.

[26] D. Cyr, Modeling web site design across cultures: Relationships to trust, satisfaction, and e-loyalty, Journal of Management Information Systems, vol. 24, no. 4, pp. 47-72, 2008.

[27] G. Darren and P. Mallery, SPSS for Windows Step by Step: A Simple Guide and Reference. 11.0 update. Boston: Allyn and Bacon, 2003.

[28] S. Devaraj, M. Fan and R. Kohli, Antecedents satisfaction and of B2C preference: Channel validating, Information Systems Research, vol. 13, no. 3, pp. 316-333, 2002

[29] R. R. Dholakia, M. Zhao and N. Dholakia, Multichannel retailing: A case study of early experiences, Journal of Interactive Marketing, vol. 19, no. 2, pp. 63-74, 2005.

[30] A. Diamantopoulos, M. Sarstedt, C. Fuchs, P. Wilczynski, and S. Kaiser, Guidelines for choosing between multiitem and single-item scales for construct measurement: A predictive validity perspective, Journal of the Academy of Marketing Science, vol. 40, no. 3, pp. 434-449, 2012.

[31] S. Dimitriadis and E. Langeard. (1990) Limits of brand extensions: An empirical study of consumer reactions to retailer's corporate brand extensions. Institut d'Administration des entreprises of Aix-en-Provence, Puyricard, 1990. Semanticscholar. [Online]. Available: https://pdfs.semanticscholar.org/977c/d9230da7c2e2ff2a0579f7594 d5f3a0f784c.pdf

[32] D. X. Ding, P. J. H. Hu, R. Verma, and D. G. Wardell, The impact of service system design and flow experience on customer satisfaction in online financial services, Journal of Service Research, vol. 13, no. 1, pp. 96-110, 2010.

[33] W. B. Dodds, K. B. Monroe and D. Grewal, Effects of price, brand, and store information on buyers' product evaluations, Journal of Marketing Research, vol. 28, no. 3, p. 307, 1991.

[34] C. Dziuban and E. Shirkey, When is a correlation matrix appropriate for factor analysis? Some decision rules, Psychological Bulletin, vol. 81, no. 6, pp. 358-361, 1974.

[35] Y. H. Fang, C. M. Chiu and E. T. G. Wang, Understanding customers' satisfaction and repurchase intentions: An integration of IS success model, trust, and justice, Internet Research, vol. 21, no. 4, pp. 479-503, 2011.

[36] C. Flavián, M. Guinalíu and R. Gurrea, The role played by perceived usability, satisfaction and consumer trust on website loyalty, Information and Management, vol. 43, no. 1, pp. 1-14, 2006.

[37] C. Fornell, M. D. Johnson, E. W. Anderson, and B. E. Bryant, The American customer satisfaction index: Nature, purpose, and findings, Journal of Marketing, vol. 60, no. 4, pp. 7-18, 1996.

[38] J. Ganesh, M. J. Arnold and K. E. Reynolds, Understanding the customer base of service providers: An examination of the differences between switchers and stayers, Journal of Marketing, vol. 64, no. 3, pp. 65-87, 2000.

[39] E. Garbarino and M. S. Johnson, The different roles of satisfaction, trust, and commitment in customer relationships, Journal of Marketing, vol. 63, no. 2, pp. 70-87, 1999.

[40] D. Gefen, E-commerce: The role of familiarity and trust, Omega, vol. 28, no. 6, pp. 725-737, 2000

[41] K. C. Gehrt and R. N. Yan, Situational, consumer, and retailer factors affecting Internet, catalog, and store shopping, International Journal of Retail \& Distribution Management, vol. 32, no. 1, pp. 5-18, 2004.

[42] J. A. Gliem and R. R. Gliem, Calculating, interpreting, and reporting cronbach's alpha reliability coefficient for likert-type scales, Midwest Research to Practice Conference in Adult, Continuing, and Community Education, no. 1992, pp. 82-88, 2003.

[43] D. Grewal, M. Levy and D. R. Lehmann, Retail branding and customer loyalty: An overview, Journal of Retailing, vol. 80 , no. 4,2004

[44] P. Guenzi, M. D. Johnson and S. Castaldo, A comprehensive model of customer trust in two retail stores, Journal of Service Management, vol. 20, no. 3, pp. 290-316, 2009.

[45] S. Gupta and H. W. Kim, The moderating effect of transaction experience on the decision calculus in on-line repurchase, International Journal of Electronic Commerce, vol. 12, no. 1, pp. 127-158, 2007.

[46] H. Ha, Factors influencing consumer perceptions of brand trust online, Journal of Products \& Brand Management, vol. 13, no. 5, pp. 329-342, 2004.

[47] S. Ha and L. Stoel, Online apparel retailing: Roles of e-shopping quality and experiential e-shopping motives, Journal of Service Management, vol. 23, no. 2, pp. 197-215, 2012. 
[48] S. Hackett and B. Parmanto, Homepage not enough when evaluating web site accessibility, Internet Research, vol. 19, no. 1, pp. 78-87, 2009.

[49] S. F. Hamilton and T. J. Richards, Product differentiation, store differentiation, and assortment depth, Management Science, vol. 55, no. 8, pp. 1368-1376, 2009.

[50] W. Hampton-Sosa and M. Koufaris, The effect of web site perceptions on initial trust in the owner company, International Journal of Electronic Commerce, vol. 10, no. 1, pp. 55-81, 2005.

[51] $\varnothing$. Helgesen, Are loyal customers profitable? Customer satisfaction, customer (action) loyalty and customer profitability at the individual level, Journal of Marketing Management, vol. 22, pp. 245-266, 2006.

[52] D. L. Hoffman, T. P. Novak and M. Peralta, Building consumer trust online, Communicarions of the ACM, vol. 42, no. 4, pp. 80-85, 2002

[53] C. Homburg, N. Koschate and W. D. Hoyer, Do satisfied customers really pay more? A study of the relationship between customer satisfaction and willingness to pay, Journal of Marketing, vol. 69, no. 2, pp. 84-96, 2005.

[54] M. Horppu, O. Kuivalainen, A. Tarkiainen, and H. K. Ellonen, Online satisfaction, trust and loyalty, and the impact of the offline parent brand, Journal of Product and Brand Management, vol. 17, no. 6, pp. 403-413, 2008.

[55] $\mathrm{H}$. Hsuehen, An empirical study of web site quality, customer value, and customer satisfaction based on e-shop, The Business Review, vol. 5, no. 1, pp. 190-193, 2006.

[56] L. T. Hu and P. M. Bentler, Cutoff criteria for fit indexes in covariance structure analysis: Conventional criteria versus new alternatives, Structural Equation Modeling, vol. 6, no. 1, pp. 1-55, 1999.

[57] C. B. Jarvis, S. B. MacKenzie and P. M. Podsakoff, A critical review of construct indicators and measurement model misspecification in marketing and consumer research, Journal of Consumer Research2, vol. 30, no. 2, pp. 199-218, 2003

[58] C. R. Jasper and P. Waldhart, Internet and distance channel use and European consumer complaint behavior, International Review of Retail, Distribution and Consumer Research, vol. 23, no. 2, pp. 137-151, 2013.

[59] P. Jiang and D. B. Jones, How third-party certification programs relate to consumer trust in online transactions: An exploratory study, Psychology \& Marketing, vol. 25, no. 9, pp. 839-858, 2008.

[60] C. Jones and S. Kim, Influences of retail brand trust, off-line patronage, clothing involvement and website quality on online apparel shopping intention, International Journal of Consumer Studies, vol. 34, no. 6, pp. 627-637, 2010

[61] J. Y. M. Kang, Repurchase loyalty for customer social co-creation e-marketplaces, Journal of Fashion Marketing and Management, vol. 18, no. 4, pp. 452-464, 2014.

[62] P. Katerattanakul and K. Siau, Creating a virtual store image, Communications of the ACM, vol. 46, no. 12, pp. 226-232, 2003.

[63] K. L. Keller, Branding shortcuts, Marketing Management, vol. 14, no. 5, pp. 18-23, 2005

[64] P. Kerkhof and G. Van Noort, Third party internet seals: Reviewing the effects on online consumer trust, Encyclopedia of E-Business Development and Management in the Global Economy, pp. 701-708, 2010.

[65] S. B. Kim and E. B. Eom, Designing effective cyber store interface, Industrial Management and Data Systems, vol. 105 , no. 5 , pp. 241-251, 2002

[66] H. W. Kim, Y. Xu and S. Gupta, Which is more important in Internet shopping, perceived price or trust?, Electronic Commerce Research and Applications, vol. 11, no. 3, pp. 241-252, 2012.

[67] J. Kim and C. Kim, E-service quality perceptions: A cross-cultural comparison of American and Korean consumers, Journal of Research in Interactive Marketing, vol. 4, no. 3, pp. 257-275, 2010.

[68] S. Kim and Y. Lee, Global online marketplace: A cross-cultural comparison of website quality, International Journal of Consumer Studies, vol. 30, no. 6, pp. 533-543, 2006.

[69] S. Kim and L. Stoel, Apparel retailers: Website quality dimensions and satisfaction, Journal of Retailing and Consumer Services, vol. 11, no. 2, pp. 109-117, 2004.

[70] Y. Kim and R. A. Peterson, A meta-analisys of online trust relationships in e-commerce, Journal of Interactive Marketing, vol. 38, pp. 44-54, 2017.

[71] T. Koivumäki, Customer satisfaction and purchasing behaviour in a web-based shopping environment, Electronic Markets, vol. 11, no. 3, pp. 186-192, 2001.

[72] M. Koufaris and W. Hampton-Sosa. (2022) Customer trust online: Examining the role of the experience with website, Semantic Scholar. [Online]. Available: https://www.semanticscholar.org/paper/CUSTOMER-TRUSTONLINE\%3A-EXAMINING-THE-ROLE-OF-THE-Koufaris-Hampton-Sosa/fc360219efe0b8b10d1ac5b6055947$5490 f 72892$

[73] M. Koufaris and W. Hampton-Sosa, The development of initial trust in an online company by new customers, Information and Management, vol. 41, no. 3, pp. 377-397, 2004.

[74] I. Küster, N. Vila and P. Canales, How does the online service level influence consumers' purchase intentions before a transaction? A formative approach, European Journal of Management and Business Economics, vol. 25, no. 3, pp. 111-120, 2016.

[75] T. W. Lauer and X. Deng, Building online trust through privacy practices, International Journal of Information Security, vol. 6, no. 5, pp. 323-331, 2007.

[76] G. Lee and H. Lin, Customer perceptions of e-service quality in online shopping, International Journal of Retail \& Distribution Management, vol. 33, no. 2, pp. 161-176, 2005.

[77] H.-H. Lee and J. Kim, The effects of shopping orientations on consumers' satisfaction with product search and purchases in a multi-channel environment, Journal of Fashion Marketing and Management: An international Journal, vol. 12, no. 2, pp. 193-216, 2008

[78] S. Lee and B. J. Cude, Consumer complaint channel choice in online and offline purchases, International Journal of Consumer Studies, vol. 36, no. 1, pp. 90-96, 2012. 
[79] S. Lee and V. S. Rao, Color and store choice in electronic commerce: The explanatory role of trust, Journal of Electronic Commerce Research, vol. 11, no. 2, pp. 110-126, 2010.

[80] Y. E. Lee and I. Benbasat, A Framework for the Study of Customer Interface Design for Mobile Commerce, International Journal of Electronic Commerce, vol. 8, no. 3, pp. 79-102, 2004.

[81] K. N. Lemon, T. B. White, and R. S. Winer, Dynamic Customer Relationship Management: Incorporating future considerations into the service retention decision, Journal of Marketing, vol. 66, no. 1, pp. 1-14, 2002.

[82] H. H. Lin and Y. S. Wang, An examination of the determinants of customer loyalty in mobile commerce contexts, Information and Management, vol. 43, no. 3, pp. 271-282, 2006.

[83] X. Liu, M. He, F. Gao, and P. Xie, An empirical study of online shopping customer satisfaction in China: A holistic perspective, International Journal of Retail \& Distribution Management, vol. 36, no. 11, pp. 919-940, 2008.

[84] M. Long and C. Mcmellon, Exploring the determinants of retail service quality on the Internet, The Journal of Services Marketing, vol. 18, no. 1, pp. 78-90, 2004.

[85] S. M. C. Loureiro, F. J. Miranda and M. Breazeale, Who needs delight?: The greater impact of value, trust and satisfaction in utilitarian, frequent-use retail, Journal of Service Management, vol. 25, no. 1, pp. 101-124, 2014.

[86] MacCallum R. C. and Browne M. W., Power analysis and determination of sample size for covariance structure modeling. , Psychological Methods, vol. 1, no. 2, pp. 130-149, 1996.

[87] G. Macintosh and L. S. Lockshin, Retail relationships and store loyalty: A multi-level perspective, International Journal of Research in Marketing, vol. 14, no. 5, pp. 487-497, 1997.

[88] C. N. Madu and A. A. Madu, Dimensions of e-quality, The International Journal of Quality \& Reliability Management, vol. 19, no. 2, pp. 246-258, 2002.

[89] N. Mallat, M. Rossi, V. K. Tuunainen, and A. Öörni, An empirical investigation of mobile ticketing service adoption in public transportation, Personal and Ubiquitous Computing, vol. 12, no. 1, pp. 57-65, 2008.

[90] R. Martenson, Corporate brand image, satisfaction and store loyalty: A study of the store as a brand, store brands and manufacturer brands, International Journal of Retail and Distribution Management, vol. 35, no. 7, pp. 544$555,2007$.

[91] K. Matzler, S. Grabner-Kräuter and S. Bidmon, Risk aversion and brand loyalty: The mediating role of brand trust and brand affect, Journal of Product \& Brand Management, vol. 17, no. 3, pp. 154-162, 2008.

[92] P. McCole, E. Ramsey and J. Williams, Trust considerations on attitudes towards online purchasing: The moderating effect of privacy and security concerns, Journal of Business Research, vol. 63, no. 9-10, pp. 10181024,2010

[93] C. Moorman, R. Deshpandé and G. Zaltman, Factors affecting trust in market research relationships, Journal of Marketing, vol. 57, no. 1, pp. 81-101, 1993.

[94] R. M. Morgan and S. D. Hunt, Commitment-trust theory of relationship marketing, Journal of Marketing, vol. 58, no. 3, pp. 20-38, 1994.

[95] T. M. Nisar and G. Prabhakar, What factors determine e-satisfaction and consumer spending in e-commerce retailing?, Journal of Retailing and Consumer Services, vol. 39, pp. 135-144, 2017.

[96] J. Ojasalo, E-service quality: A conceptual model 2. The concept and characteristics of e-services, International Journal of Arts and Sciences, vol. 3, no. 7, pp. 127-143, 2010.

[97] R. Oliver, Whence consumer loyalty?, Journal of Marketing, vol. 63, no. Special Issue, pp. 33-44, 1999.

[98] S. O. Olsen, Comparative evaluation and the relationship between quality, satisfaction, and repurchase loyalty, Journal of the Academy of Marketing Science, vol. 30, no. 3, pp. 240-249, 2002.

[99] M. Z. Osman, A conceptual model of retail image influences on loyalty patronage behaviour, The International Review of Retail, Distribution and Consumer Research, vol. 3, no. 2, pp. 133-148, 1993.

[100] A. Parasuraman and D. Grewal, The impact of technology on the quality value loyalty chain: A research agenda, Journal of the academy of marketing science, vol. 28, no. 1, pp. 168-174, 2000.

[101] A. Parasuraman, V. A. Zeithaml and A. Malhotra, E-S-QUAL a multiple-item scale for assessing electronic service quality, Journal of Service Research, vol. 7, no. 3, pp. 213-233, 2005.

[102] P. A. Pavlou, Consumer acceptance of electronic commerce: Integrating trust and risk with the technology acceptance model, International Journal of Electronic Commerce, vol. 7, no. 3, pp. 101-134, 2003

[103] A. Petersen, Private matters: it seems that trust equals revenue, even online, Wall Street Journal, Europe, p. 8, 2001.

[104] C. Ranganathan and S. Ganapathy, Key dimensions of business to consumer web sites', Information and Management, vol. 39, no. 01, pp. 457-465, 2002.

[105] S. Rao, S. E. Griffis and T. J. Goldsby, Failure to deliver? Linking online order fulfillment glitches with future purchase behavior, Journal of Operations Management, vol. 29, no. 7-8, pp. 692-703, 2011.

[106]D. J. Reibstein, What attracts customers to online stores, and what keeps them coming back?, Journal of the Academy of Marketing Science, vol. 30, no. 4, pp. 465-473, 2002.

[107] P. Reicheld and F.F. dan Schefter, E-loyalty: Your secret weapon on the web, Harvard Business Review, vol. 78, no. 4, pp. 105-113, 2000

[108] W. J. Reinartz and V. Kumar, The impact of customer relationship characteristics on profitable lifetime duration, Journal of Marketing, vol. 67, no. 1, pp. 77-99, 2003.

[109]J. Reynolds, eCommerce: A critical review Jonathan Reynolds: Director of the Oxford Institute of retail management, International Journal of Retail \& Distribution Management, vol. 28, no. 10, pp. 417-444, 2000.

[110]S. Rezaei and M. Amin, Exploring online repurchase behavioural intention of university students in Malaysia, Journal for Global Business Advancement, vol. 6, no. 2, p. 92, 2013.

[111]D. Ribbink, A. C. R. van Riel, V. Liljander, and S. Streukens, Comfort your online customer: Quality, trust and loyalty on the internet, Managing Service Quality, vol. 14, no. 6, pp. 446-456, 2004 
[112] S. Rose, M. Clark, P. Samouel, and N. Hair, Online customer experience in e-retailing: An empirical model of antecedents and outcomes, Journal of Retailing, vol. 88, no. 2, pp. 308-322, 2012.

[113]K. Ryu and H. Han, Influence of the quality of food, service, and physical environment on customer satisfaction and behavioral intention in quick-casual restaurants: Moderating role of perceived price, Journal of Hospitality and Tourism Research, vol. 34, no. 3, pp. 310-329, 2010.

[114] C. M. Sabiote, D. M. Frías and J. A. Castañeda, The moderating effect of uncertainty-avoidance on overall perceived value of a service purchased online, Internet Research, vol. 22, no. 2, pp. 180-198, 2012.

[115] J. Salo and H. Karjaluoto, A conceptual model of trust in the online environment, Online Information Review, vol. 31, no. 5, pp. 604-621, 2007.

[116]K. Seiders, G. B. Voss, D. Grewal, and A. L. Godfrey, Do satisfied customers buy more? Examining moderating influences in a retailing context, Journal of Marketing, vol. 69, no. 4, pp. 26-43, 2005.

[117]J. Semeijn and O. Universiteit, E-services and offline fulfilment: How e- loyalty is created, Journal of Service Theory and Practice, vol. 15, no. 2, pp. 182-194, 2005.

[118] J. Singh and D. Sirdeshmukh, Agency and trust mechanisms in customer satisfaction and loyalty judgements, Journal of the Academy of Marketing Science, vol. 28, no. 1, pp. 150-167, 2000

[119]D. Sirdeshmukh, J. Singh and B. Sabol, Consumer trust, value, and loyalty in relational exchanges, Journal of Marketing, vol. 66, no. 1, pp. 15-37, 2002.

[120]S. S. Srinivasan, R. Anderson and K. Ponnavolu, Customer loyalty in e-comerce: An exploration of its antecedents and consequences, Journal of Retailing, vol. 78, no. 1, pp. 41-50, 2002.

[121]J.-C. Suh and Y. Yi, When brand attitudes affect the customer satisfaction and loyalty relationship: The moderating role of product involvement, Journal of Consumer Psychology, vol. 16, no. 2, pp. 145-155, 2006.

[122] Y. W. Sullivan and D. J. Kim, Assessing the effects of consumers' product evaluations and trust on repurchase intention in e-commerce environments, International Journal of Information Management, vol. 39, pp. 199-219, 2018.

[123]D. M. Szymanski and R. T. Hise, E-satisfaction: An initial examination, Journal of Retailing, vol. 76, no. 3, pp. 309-322, 2000.

[124]N. Tamimi, M. Rajan and R. Sebastianelli, The state of online retailing, Internet Research, vol. 13, no. 3, pp. 146$155,2003$.

[125]S. Tobias and J. E. Carlson, Brief report: Bartlett'S test of sphericity and chance findings in factor analysis, Multivariate Behavioral Research, vol. 4, no. 3, pp. 375-377, 1969.

[126]G. Torkzadeh and G. Dhillon, Measuring factors that influence the success of e-government initiatives, Information Systems Research, vol. 13, no. 2, pp. 187-204, 2002.

[127] G. L. Urban, F. Sultan and W. J. Qualls, Placing trust at the center of your internet strategy, Sloan Management Review, vol. 42, no. 1, pp. 39-48, 2000.

[128] A. Vos, C. Marinagi, P. Trivellas, N. Eberhagen, G. Giannakopoulos, and C. Skourlas, Electronic service quality in online shopping and risk reduction strategies, Journal of Systems and Information Technology, vol. 16, no. 3, pp. 170-186, 2014.

[129] G. B. Voss, A. Godfrey and K. Seiders, How complementarity and substitution alter the customer satisfactionrepurchase link, Journal of Marketing, vol. 74, no. 6, pp. 111-127, 2010.

[130]Y. J. Wang, M. D. Hernandez and M. S. Minor, Web aesthetics effects on perceived online service quality and satisfaction in an e-tail environment: The moderating role of purchase task, Journal of Business Research, vol. 63, no. 9-10, pp. 935-942, 2010.

[131]F. E. Webster, Understanding the relationships among brands, consumers, and resellers, Journal of the Academy of Marketing Science, vol. 28, no. 1, pp. 17-23, 2000.

[132] C. Wen, V. R. Prybutok, C. Blankson, and J. Fang, The role of e-quality within the consumer decision making process, International Journal of Operations \& Production Management, vol. 34, no. 12, pp. 1506-1536, 2014.

[133]B. Wheaton, B. Muthén, D. F. Alwin, and G. F. Summers, Assessing reliability and stability in panel models, Sociological Methodology, vol. 8, pp. 84-136, 1977.

[134]B. N. Wingfield, M. Rose, W. Street, and B. B. Feb, Amazon is split on charging fees to plug books, Wall Street Journal, Europe, p. 23, 2001.

[135]M. Wolfinbarger and M. C. Gilly, eTailQ: Dimensionalizing, measuring and predicting etail quality, Journal of Retailing, vol. 79, no. 3, pp. 183-198, 2003.

[136] M. Wolfinbarger and M. C. Gilly, Shopping online for freedom, control and fun, California Management Review, vol. 43, no. 2, pp. 34-55, 2001.

[137]B. Yang and D. Lester, Attitudes toward buying online, CyberPsychology \& Behavior, vol. 7, no. 1, pp. 85-91, 2004.

[138]Z. Yang and X. Fang, Online service quality dimensions and their relationships with satisfaction: A content analysis of customer reviews of securities brokerage services, International Journal of Service Industry Management, vol. 15, no. 3, pp. 302-326, 2004.

[139]Y. S. Yeh and Y. M. Li, Building trust in m-commerce: Contributions from quality and satisfaction, Online Information Review, vol. 33, no. 6, pp. 1066-1086, 2009.

[140] C. H. Yen and H. P. Lu, Effects of e-service quality on loyalty intention: An empirical study in online auction, Managing Service Quality, vol. 18, no. 2, pp. 127-146, 2008

[141] S.-J. Yoon, The antecedents and consequences of trust in virtual community, Journal of interactive marketing, vol. 16, no. 2, pp. 47-63, 2002.

[142] H. Yu, Web accessibility and the law: Recommedations for implementation, Library Hi Tech, vol. 20, no. 4, pp. 406-419, 2002. 
[143] J. J. Zboja and C. M. Voorhees, The impact of brand trust and satisfaction on retailer repurchase intentions, Journal of Services Marketing, vol. 20, no. 6, pp. 381-390, 2006.

[144] V. Zeithaml, Consumer perceptions of price, quality, and value: A means-end model and synthesis of evidence, Journal of Marketing, vol. 52, no. 3, p. 22, 1988.

[145] V. A. Zeithaml, L. L. Berry and A. Parasuraman, The behavioral consequences of service quality, Journal of Marketing, vol. 60, no. 2, pp. 31-46, 1996.

[146] V. A. Zeithlam, A. Parasuraman and A. Malhotra, A Conceptual Framework for Understanding E-Service Quality: Implications for Future Research and Managerial Practice. Cambridge, MA, 2000. 


\section{Appendix 1: Pearson Correlation Matrix. Observed Variables with Higher Measurement Weights}

\begin{tabular}{|c|c|c|c|c|c|c|c|c|c|c|}
\hline & 1 & 2 & 3 & 4 & 5 & 6 & 7 & 8 & 9 & 10 \\
\hline 1 Home page & 1 & $.62^{* *}$ & $.60^{* *}$ & $.46^{* *}$ & $.59^{* *}$ & $.61^{* *}$ & $.62^{* *}$ & $.62^{* *}$ & $.59^{* *}$ & $.48^{* *}$ \\
\hline 2 Catalog & $.62^{* *}$ & 1 & $.69^{* *}$ & $.58^{* *}$ & $.62^{* *}$ & $.65^{* *}$ & $.69^{* *}$ & $.68^{* *}$ & $.65^{* *}$ & $.52^{\star *}$ \\
\hline 3 Order form & $.60^{* *}$ & $.69^{* *}$ & 1 & $.60^{* *}$ & $.62^{* *}$ & $.64^{* *}$ & $.75^{\star *}$ & $.68^{* *}$ & $.70^{* *}$ & $.58^{* *}$ \\
\hline 4 Support & $.46^{* *}$ & $.58^{* *}$ & $.60^{* *}$ & 1 & $.53^{* *}$ & $.53^{* *}$ & $.69^{* *}$ & $.56^{* *}$ & $.60^{* *}$ & $.50^{* *}$ \\
\hline 5 Product brand & $.59^{* *}$ & $.62^{* *}$ & $.62^{* *}$ & $.53^{* *}$ & 1 & $.84^{* *}$ & $.69^{* *}$ & $.77^{* *}$ & $.75^{* *}$ & $.47^{* *}$ \\
\hline 6 Store brand & $.61^{* \star}$ & $.65^{* *}$ & $.64^{* *}$ & $.53^{* *}$ & $.84^{* *}$ & 1 & $.72^{* \star}$ & $.80^{* *}$ & $.76^{* *}$ & $.51^{* *}$ \\
\hline 7 Satisfaction & $.62^{* *}$ & $.69^{* *}$ & $.75^{* *}$ & $.69^{* *}$ & $.69^{* *}$ & $.72^{\star *}$ & 1 & $.75^{\star *}$ & $.75^{\star \star}$ & $.56^{* *}$ \\
\hline 8 Trust & $.62^{* *}$ & $.68^{* *}$ & $.68^{* *}$ & $.56^{* *}$ & $.77^{* *}$ & $.80^{* *}$ & $.75^{* *}$ & 1 & $.73^{* *}$ & $.58^{* *}$ \\
\hline 9 Intentions & $.59^{* *}$ & $.65^{* *}$ & $.70^{* *}$ & $.60^{* *}$ & $.75^{* *}$ & $.80^{* *}$ & $.75^{* *}$ & $.73^{* *}$ & 1 & $.63^{* *}$ \\
\hline 10 Repurchase & $.48^{* *}$ & $.52^{* *}$ & $.58^{\star *}$ & $.50^{* *}$ & $.47^{* *}$ & $.51^{* *}$ & $.56^{* *}$ & $.58^{* *}$ & $.63^{* *}$ & 1 \\
\hline
\end{tabular}

